ББК 081.73-1

\title{
RHIZOSPHERIC TROPHIC CHAIN: THE ROLE AND STABILITY IN SOIL PROCESSES AND ECOSYSTEMS
}

\author{
Patyka Nikolay Vladimirovich \\ Head of Department of Agricultural Microbiology and Plant Physiology, \\ National Scientific Centre, Institute of Agriculture of the National Academy \\ of Agrarian Sciences of Ukraine \\ n_patyka@mail.ru \\ Sadovaya St., 23, 03027 Kiev-27 (Novoselki), Ukraine
}

\section{Bublik Nikolay Aleksandrovich}

First Deputy Director of the Institute of Horticulture of the National Academy of Agrarian Sciences of Ukraine mbublyk@mail.ru Sadovaya St., 23, 03027 Kiev-27 (Novoselki), Ukraine

\section{Patyka Tatyana Ivanovna}

Head of Laboratory of Plant Physiology and Microbiology, Institute of Horticulture of the National Academy of Agrarian Sciences of Ukraine n_patyka@mail.ru Sadovaya St., 23, 03027 Kiev-27 (Novoselki), Ukraine

\section{Kitaev Oleg Igorevich}

\author{
Leading Researcher, Laboratory of Plant Physiology and Microbiology, \\ Institute of Horticulture of the National Academy of Agrarian Sciences of Ukraine \\ n_patyka@mail.ru \\ Sadovaya St., 23, 03027 Kiev-27 (Novoselki), Ukraine
}

\begin{abstract}
The authors have investigated the problems of interactions in the rhizosphere in the context of changing trophic connections, their resilience in ecosystems. It is shown that the dynamics of rhizosphere interactions with changes in environmental conditions becomes the focus of intensive research and the development of continuum enrichment area at the roots and the formation of systems of their interaction in the soil profile.
\end{abstract}

Key words: rhizosphere, ecosystem, trophic interactions, food webs.

The composition of the rhizosphere includes the root system of plants and surrounding soil, which is experiencing its effects. This definition is broader than the traditional definition, including the roots and the soil, which is adjacent to them (Coleman, 1996; Van der Putten, 2001; Moore, 
2003). The traditional definition ignores important biological interactions with soil biota, as it forms the structure of the soil, which is often regarded as the physical processes, while forgetting about the biologically active complex and the environment.

Rhizosphere is a trophic food webs producers and consumers with a variety of complex organisms (bacteria, micromycetes protozoa and plant root system). There is a definition, which includes features that characterize the formation of biological systems of soil organisms:

1) the use of various energy resources with different speeds for their use;

2) the presence of different life cycles;

3 ) variety of habitats.

Trophic interactions in the rhizosphere is necessary to study how complex this submatery is as a unit. In modern science, there is a clear justification for this kind of research (Bender, 1984; O’Neill, 1986; Yodzis, 1996), especially when it comes to sets of identical and intertwine dynamics caused by species characteristics, trophic food chains, the level of conservation of the population and rates growth.

Any biological processes can be justified and presented in the form of models that reflect the complex relationship. We are all familiar with the chemical formulation that gives the primary idea of the basis of the equation of life: $6 \mathrm{CO}_{2}+6 \mathrm{H}_{2} \mathrm{O}=\mathrm{C}_{6} \mathrm{H}_{12} \mathrm{O}_{6}+6 \mathrm{O}_{2}(1)$.

Equation 1 includes several concepts. It illustrates the conservation of matter, as each side of the equation is composed of various molecules, but an equal number of atoms and mass. This chemical equation is set as underlying model reflecting rhizospheric interaction. Besides, the presentation of photosynthesis and respiration, equation 1 represents the relationship between the processes of synthesis and degradation of working at different scales, for example, autotrophic and heterotrophic processes of interaction between plants and herbivores, immobilization of inorganic matter into organic matter and vice versa.

Of course, the biology is not only of carbon, water, hydrogen and rhizosphere basic functions of biological processes lie in the transformation of nutrients such as nitrogen and phosphorus. If nitrogen is added to the equation, while taking into account that the different kinds of microorganisms contained in the biomass of a different ratio of $\mathrm{N}, \mathrm{P}, \mathrm{C}$, and other elements (different stoichiometry), a similar system of equations and related processes forms the interrelationship of elements in the formation basic necessities of life (Reiners, 1986). When carbon and nitrogen are localized in the organic matter and mineralized into inorganic matter, there are various aspects of formation of bonds from more narrowly focused overground and underground processes to interorganismal by forming biogeochemical pathways immobilization of inorganic metabolites and vice versa. There are the same trophic circuitry used to describe trophic interactions (Moore, 2005).

Thus, the use of mathematical modeling (models underlying the rhizosphere functions) necessary for the development of ideas about the stoichiometry and trophic relationships (energy flows) in the rhizosphere. On the one hand, effective models are internally consistent, structurally simple and ideological. On the other hand, the lack of parts, making them interesting biologically, which thus leads to biologically nonlinear inexplicable results. A good example of the latter is unstable mathematical concepts of the theory of mutualistic relationships (Pimm, 1982), in contrast to the classical concept of the formation of symbiotic mutualism, which is formed in the rhizosphere.

To get information about mathematically functional orientation in the rhizosphere, it is important to determine the flow of resources in the rhizosphere, which will form a part thereof, and what will be emphasized. What volume of carbon-containing products of photosynthesis exudates produced by plants produced root system during ontogeny plants which provide the basic framework for the formation of rhizosphere soil. Formation of the rhizosphere caused a rapid and vigorous growth of the root system, which includes twisting of root hairs, death of individual roots and exudation of carbon compounds. The size and dynamics of the formation of the rhizosphere differentiated according to the above-ground biomass, species and ecosystem types. When there is a significant difference in the ratios of contrasting sizes in plants causes may be to limit the ratio of nutrients in the $\mathrm{C}: \mathrm{N}$ and $\mathrm{C}: \mathrm{P}$ and selective factor for food resources. A constant ratio and differentiation depending on resource 
streams greatly simplifies and makes reliable formation of such models.

Carbon fluxes in the rhizosphere help to maintain the function of providing the rhizosphere resource necessary for the formation of a mathematical model. The studies of rhizosphere indicate that the growth zone of the root system can be divided into zones of a continuum of activity from the root tip to the side chain, where the various microbial groups have access to the downstream root exudates organic (Trofymow, Coleman, 1982).

The tip of the root is the lowest root zone. The zone is characterized by the growth of the root rapidly dividing cells and the activity to produce exudates, which also reduces the resistance of the soil. Exudates produced by cells of the roots, provide catering carbon rhizosphere bacteria and fungi, which, in turn, immobilized compounds of nitrogen and phosphorus. At a distance from the zone of root growth nutrient exchange sites are formed, which are formed. Formation and death of root hairs defines additional activity and growth of microorganisms. The upper zone of the root system of plants are characterized as areas of remineralization of nutrients that perform predators, as there are regions of mutualistic symbiotic interactions. In each of the areas of the rhizosphere of plants the production of root system of carbonaceous substances that determine the growth and activity of the rhizosphere microflora (Bringhurst, 2001), protozoa takes place and invertebrates that feed on them (Lussenhop, Fogel, 1991; Parmelee, 1993).

Mathematical description of the trophic food chains in the rhizosphere is based on three kinds of food links (Paine, 1980) - uptake, release of energy and interaction. Each description is based on the view signalling required for their formation.

Description of the relationship based on the study of the rhizosphere of species and changes in their metabolism. Given the extent and size of populations and the interaction of soil microorganisms and the simplest, most of the data presented in the literature, based on the study of trophic interactions in soil samples collected volumes of information, research areas, etc. Description provided by relations, despite the volumes of the information received is incomplete and strongly negates the study of diversity and complexity of forming the system.
Chain constant interaction reflects the dynamics influence of one group on another. For example, these descriptions were taken as the basis of several research groups attempted to link the structure of the soil food webs with the transformation of organic matter and mineralization of primary cells (Hunt, 1987; de Ruiter, 1993; Brussaard, 1997).

Considering the laws of formation of structure of trophic food chains rhizosphere should be noted that the communication and distribution of energy flows exhibit two patterns, the presence and level of nutrients and biomass within the system that is important for its stability. The first has to do with the flow of energy from the roots and soil biota to higher predators. The constant supply of nutrients in the rhizosphere is a complex process and is determined by several species of dominant microorganisms that function directly in the root system (the so-called complex of plantmicrobial energy flows, which occur in the process of differentiation in terms of resource use various physiological and functional scenarios) (Hunt, 1987; Moore, 1988).

Basic food items of insects and nematodes, pathogens and microorganisms that have symbiotic relationship with the roots of plants are the basis of rhizosphere energy canals. Bacterial energy canal consists of saprophytic bacteria, protozoa, nematodes and some arthropods. Fungi canal energy is largely composed of saprophytic fungi, nematodes and arthropods. Soil bacteria constitute a significant part of the microbial biomass in the rhizosphere, and are more efficient in the use of labile root exudates than saprophytic fungi. Unlike bacteria, fungi are more adapted for the use of plant residues. In addition, fungi's and their consumers in the soil occupied by air pores, voids, and live longer. Nutrients within each trophic canal are transformed at different rates, given the characteristics of the substances, which use bacteria and fungi. Coleman (1983) found that the differentiation of flows of nutrients due to the formation rate of the food chains because the bacterial energy channel generates a "fast cycle", while the fungi - "slow loop". It is important to note that the mathematical foundation structure of the rhizosphere microbial complex, which forms the system and different dynamic properties, more stable diversity 
(representation of the group) and complexity (number of links between groups) than in the formation of random (spontaneous) designs.

Modern research has established that the structure of the trophic pyramid is more stable than the alternative structure, such as an inverted pyramid with a higher biomass, supported by higher trophic levels (Moore, de Ruiter, 2000; Neutel, 2002).

In addition to the foregoing distribution patterns different biomass and energy flows, coupling constants are asymmetric nature of the interaction, i.e. observed beneficial effect for consumers, and vice versa, which depends on the trophic levels. On lower trophic levels, consumers have a strong negative impact on producers and on higher trophic levels producers positively affect consumers. This structuring in close cooperation related to the stability of soil trophic food chains.

Thus, the structure of the interaction forces is closely related to the distribution of biomass and the rate of application of exudates and evaluation are integral components of the interaction forces. Redistribution of the level of interaction simultaneously redistributes biomass and substrate utilization.

Emphasizing the important role of soil biota, functioning and is defined in the rhizosphere of the growth and dynamics of communities, the study of soil as a reservoir of plant nutrients and restrictions are still widespread and are particularly relevant in the consideration and study of the trophic chains, dynamics and development of plant communities. Rhizosphere better studied as a set of individual taxonomic group, and the work not only in the complex, but also has a selfregulating properties (especially when it comes to pool metagenome with similar and interrelated behavior, especially species). Food flows rhizosphere are complex functioning complexes related organisms (bacterial, fungal, root systems and their users). A key distinguishing feature of the complexes is their ability to transform the different types of energy resources at different speeds, characterized by different life cycles and occupy habitats. Organisms within the canal of bacterial and fungal energy responsive to a varying degree of interaction as a unit.

Studies of meadow lands, forest and arctic tundra agricultural systems suggest that the relationship between the energy flows are generally weak on trophic levels associated with bacterial and fungal microflora and stronger with the simplest. Bonding strength between the energy flow and dominance of a particular depends on the type of ecosystem may vary in certain disorders and controls the flow of nutrients (Fig. 1).

Using mathematical models, scientists have shown a link between nutrient flow, the level of interaction between communities (Moore, 2003; de Ruiter, 1995).

Research and models suggest that polymorphism structure is not only important for transfer and storage of nutrients in the system, but also for its homeostasis in general. Modern research has demonstrated the formation of food

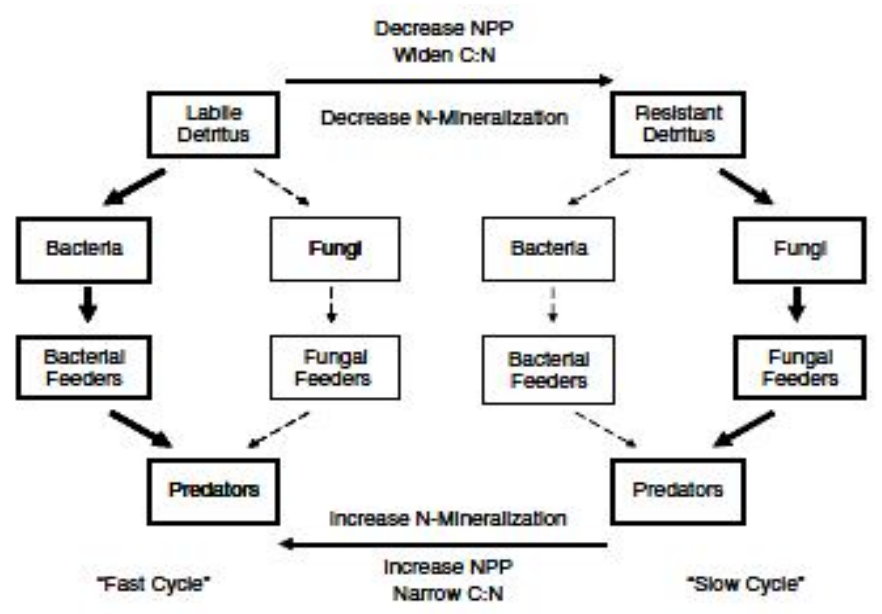

Fig. 1. Generalized bacterial and fungal energy flows in the food web of the rhizosphere (Moore, 2003) 
webs in the rhizosphere as a complex multistage system, which functions as a single organism, which allows to control the flow of nutrients between the producer and the consumer. It is thought that changes in the structure of the basic foundations of the rhizosphere and the rate of passage of nutrient flows are crucial in key processes that shape the ecosystem as a whole. Lack script processes allelopathy destroy the link between the trophic structure, dynamics and transformation proceeds of nutrients, and the lack of homeostasis observed in the rhizosphere under uncontrolled anthropogenic load.

\section{REFERENCES}

1.Bender E.A., Case T.J., Gilpin M.E. Perturbation Experiments in Community Ecology: Theory and Practice. Ecology, 1984, vol. 65, pp. 1-13.

2. Bringhurst R.M., Cardon Z.G., Gage D.J. Galactosides in the Rhizosphere: Utilization by Sinorhizobium meliloti and Development of a Biosensor. Proceedings of the National Academy of Sciences of the USA, 2001, vol. 98, pp. 4540-4545.

3. Brussaard L., Behan-Pelletier V.M., Bignell D.E., eds. Biodiversity and Ecosystem Functioning in Soil. Ambio, 1997, vol. 26, pp. 563-570.

4. Coleman D.C. Energetics of Detritivory and Microbivory in Soil in Theory and Practice. Polis G.A., Winemiller K.O., eds. Food Webs: Integration of Patterns and Dynamics. New York, Chapman Hall, 1996, pp. 39-50.

5. de Ruiter P.C., Neutel A., Moore J.C. Energetics, Patterns of Interaction Strengths and Stability in Real Ecosystems. Science, 1995, vol. 269, pp. 1257-1260.

6. de Ruiter P.C., Van Veen J.A., Moore J.C., eds. Calculation of Nitrogen Mineralization in Soil Food Webs. Plant Soil, 1993, vol. 157, pp. 263-273.

7. Hunt H.W., Coleman D.C., Ingham E.R., eds. The Detrital Food Web in a Shortgrass Prairie. Biology and Fertility of Soils, 1987, vol. 3, pp. 57-68.

8. Lussenhop J., Fogel R. Soil Invertebrates Are Concentrated on Roots. Keiser D.L., Cregan P.B., eds. The Rhizosphere and Plant Growth. Dordrecht, Kluwer Academic Publishers, 1991, p. 111.
9. Moore J.C., Hunt H.W. Resource Compartmentation and the Stability of Real Ecosystems. Nature, 1988, vol. 333, pp. 261-263.

10. Moore J.C., de Ruiter P.C. Invertebrates in Detrital Food Webs Along Gradients of Productivity. Coleman D.C., Hendrix P.F., eds. Invertebrates as Webmaster in Ecosystems. New York, CABI, 2000, pp. 161-184.

11. Moore J.C., McCann K., Setdldv H., de Ruiter P.C. Top-Down is Bottom-Up: Does Predation in the Rhizosphere Regulate Aboverground Production? Ecology, 2003, vol. 84, pp. 846-857.

12. Moore J.C., McCann K., de Ruiter P.C. Modeling Trophic Pathways, Nutrient Cycling, and Dynamic Stability in Soils. Pedobiology, 2005, vol. 49, pp. 499-510.

13. Neutel A.M., Heesterbeek J.A.P., de Ruiter P.C. Stability in Real Food Webs: Weak Links In Long Loops. Science, 2002, vol. 296, pp. 1120-1123.

14. O’Neill R.V., DeAngelis D.L., Waide J.B., Allen T.F.H. A Hierarchical Concept of the Ecosystem. Princeton, Princeton University Press, 1986.

15. Pimm S.L. Food Webs. London, Chapman Hall, 1982.

16. Parmelee R.W., Ehrenfeld J.G., Tate R.L. Effects of Pine Roots on Microorganisms, Fauna, and Nitrogen Availability in Two Soil Horizons of a Coniferous Spodosol. Biology and Fertility of Soils, 1993, vol. 15, pp. 113-119.

17. Paine R.T. Food Webs: Linkages, Interaction Strength and Community Infrastructure. Journal of Animal Ecology, 1980, vol. 49, pp. 667-685.

18. Reiners W.A. Complementary Models for Ecosystems. American Naturalist, 1986, vol. 127, pp. 59-73.

19. Trofymow J.A., Coleman D.C. The Role of Bacterivorous and Fungivorous Nematodes in Cellulose and Chitin Decomposition in the Context of a Root [Rhizosphere] Soil Conceptual Model. Freckman D.W., ed. Nematodes in Soil Ecosystems. Austin, University of Texas Press, 1982, pp. 117-137.

20. Van der Putten W.H.L., Vet E.M., Harvey J.A., Wdckers F.L. Linking Above- and Belowground Multitrophic Interactions of Plants, Herbivores, Pathogens, and Their Antagonists. TREE, 2001, vol. 16, pp. 547-554.

21. Yodzis P. Food Webs and Perturbation Experiments: Theory and Practice. Polis G.A., Winemiller K.O., eds. Food Webs: Integration of Patterns and Dynamics. New York, Chapman Hall, 1996, pp. 192-200. 


\section{ОЦЕНКА ВЛИЯНИЯ РИЗОСФЕРНОЙ ТРОФИЧЕСКОЙ ЦЕПИ \\ НА СТАБИЛЬНОСТЬ ПОЧВЕННЫХ ПРОЦЕССОВ И ЭКОСИСТЕМ}

\section{Патыка Николай Владимирович}

Начальник отдела сельскохозяйственной микробиологии и физиологии растений Национального научного центра,

Институт земледелия Национальной академии аграрных наук Украины

n_patyka@mail.ru

ул. Садовая, 23, 03027, Киев-27 (Новоселки), Украина

\section{Бублик Николай Александрович}

Первый заместитель директора Института садоводства, Национальная академия аграрных наук Украины mbublyk@mail.ru ул. Садовая, 23, 03027, Киев-27 (Новоселки), Украина

\section{Патыка Татьяна Ивановна}

Заведующая лабораторией физиологии растений и микробиологии, Институт садоводства Национальной академии аграрных наук Украины n_patyka@mail.ru ул. Садовая, 23, 03027, Киев-27 (Новоселки), Украина

\section{Китаев Олег Игоревич}

Ведущий научный сотрудник лаборатории физиологии растений и микробиологии, Институт садоводства Национальной академии аграрных наук Украины n_patyka@mail.ru ул. Садовая, 23, 03027, Киев-27 (Новоселки), Украина

Аннотация. Авторы рассмотрели проблемы взаимодействия в ризосфере через призму изменения трофических связей, их устойчивости в экосистемах. Показано, что взаимодействия в ризосфере с изменениями в условиях окружающей среды оказывают влияние на динамику обогащения зоны у корней и формирование системы их взаимодействия в почвенном профиле.

Ключевые слова: ризосфера, экосистема, трофические взаимодействия, пищевые сети. 